\title{
Environmental influences on winter spawning of the anchoveta Engraulis ringens off central Chile
}

\author{
Leonardo R. Castro*, Gustavo R. Salinas, Eduardo H. Hernández \\ Departamento de Oceanografia, Universidad de Concepcion, Casilla 160-C, Concepcion, Chile
}

\begin{abstract}
Previous studies on clupeiform reproduction have suggested that in upwelling areas of permanently high wind speed, winter spawning could be selected to promote the retention of offspring close to the coast, where more benign conditions are supposed to exist. The role of winter environmental characteristics, other than those conducive to retention, that could represent trade-offs within this strategy (i.e. larval food limitation, water temperature, intrusion of oceanic predators), however, have traditionally not been assessed. In the present paper, we assess the role of environmental variability on the winter reproductive strategy of the anchovy Engraulis ringens in an area close to its southern limit of distribution. A series of 8 cruises were conducted during the winter of 1995 in the coastal zone off Talcahuano $\left(37^{\circ} \mathrm{S}\right)$. Wind field, satellite sea surface temperature and hydrographic characteristics of the water column revealed strong short-term variability of oceanographic conditions in the nearshore area. During winter, upwelling events, a broad river plume and a cross shelf circulation were determined. Peak anchovy egg and larval densities occurred regularly at the nearshore stations. Increases in larval densities at an offshore station (12 nautical miles offshore) coincided with periods of coastal upwelling and the presence of a broad river plume, suggesting rapid transport of larvae from the coast. Maximum densities of gelatinous predators, in turn, coincided with the periods of minimum larval densities offshore, creating an apparent inverse relationship. Predators and larvae, however, did not co-occur in the same water masses, as revealed by the sea surface temperature and hydrography. Despite winter conditions, overall microplankton density in the water column was high during most of the season, with maximum anchovy egg and larval densities co-occurring with peak periods in larval food abundance. The coupling between maximum egg and larval fish density and specific meteorological and oceanographic conditions, the temporal and spatial decoupling between potential gelatinous predators and larval anchovies, and the overall benign larval feeding conditions close to the coast suggest that the timing of spawning and location of young anchovies nearshore may be part of a larger reproductive strategy of this species in the area.
\end{abstract}

KEY WORDS: Anchovy - Upwelling · Spawning - Clupeiforms · Jellyfish - Reproductive strategy · Engraulis · Larval food · Ichthyoplankton · Fish larvae

\section{INTRODUCTION}

Several hypotheses have been proposed to explain both recruitment variability in fish populations and the potential reproductive strategies adopted by fish to ensure their persistence. Particular attention has been given to those models relating environmental variability and the fate of early life stages. Matching the spawning periods with peak production seasons to ensure larval food availability at the onset of feeding

•E-mail: lecastro@udec.cl
(Cushing 1975, Sherman et al. 1989, Castro \& Cowen 1991) and/or spawning during periods of reduced risk to predation (Johannes 1978, Foster 1987), are 2 alternatives which have been widely discussed. Timing spawning to ensure optimum environmental conditions at the onset of metamorphosis (Sinclair \& Tremblay 1984) has also been proposed for species in coastal areas. In other, more remote environments, such as around oceanic islands, the strategies proposed involve timing the reproductive period with seasons in which oceanographic structures such as eddies or local currents occur so as to promote larval retention (Lobel \& Robinson 1986, 1988, Lobel 1989, 
Boehlert et al. 1992, Cowen \& Castro 1994, Castro 1995). Finally, for clupeiforms in coastal upwelling areas, spawning during periods of moderate winds should be favored to enhance larval survival (Cury \& Roy 1989, Roy et al. 1992).

For coastal populations in upwelling areas of permanently high wind speed, however, one of the major constraints is the need for offspring retention close to shore, where more benign conditions are supposed to exist (Parrish et al. 1981, Bakun \& Parrish 1982). In most of these highly dynamic environments, therefore, coastal fish populations should tend to synchronize their reproduction with those periods when oceanographic features or characteristics of the local hydrodynamics would retain their offspring close to the coast or in a nearby nursery habitat. In the California Current, where differences in wind speed and direction occur along the coast, populations located at different latitudes show differences in their reproductive strategies (Parrish et al. 1981). At the northern limit of the California Current, for instance, where coastal upwelling occurs mainly during spring and summer, coastal fish populations tend to reproduce during winter, when surface transport is towards the coast. In the southern area of the California Current, where upwelling is less seasonal, coastal fish populations reproduce mainly in areas where recirculation processes may be utilized for larval retention. Other retention mechanisms in zones of protracted upwelling seasons are the surface transport of larvae during relaxation events, location of the spawn at depth (below the surface Ekman layer), and the utilization of vertical migrations to counteract seaward transport during upwelling (Peterson et al. 1979, Barnett et al. 1984, Brewer \& Kleppel 1986, Jahn \& Lavenberg 1986, Castro et al. 1993).

Timing the reproduction to a particular season, however, usually involves a compromise between benefits and costs that must be confronted by the different populations. In coastal upwelling areas along eastern boundary regions (i.e. California and Chile), for instance, reproducing during the summer upwelling season may benefit the young offspring by placing them in an environment of increased food abundance. Summer spawning, however, may not be advantageous, as the oceanographic upwelling regime may induce egg and larval transport offshore (i.e. in the Ekman layer), where benign feeding conditions may not exist (Parrish et al. 1981, Bakun \& Parrish 1982). Furthermore, if upwelling, driving winds are too strong, the potential formation of microlayers rich in larval food may be precluded (Lasker 1975, 1978). Finally, because the abundance of potential predators also increases in spring and summer (i.e. jellyfish), eggs and larval fish may be subjected to increased predation during these seasons (Palma 1994, Palma \& Rosales
1995). Early life stages of winter-spawning fish populations, alternatively, may benefit from the shoreward circulation induced, in winter, by the winds favorable to downwelling (Arcos \& Navarro 1986) and from the reduced predation by jellyfish; however, they may be exposed to a more restricted abundance of larval food during this less productive season.

The anchovy Engraulis ringens, with its wide distribution range $\left(4^{\circ} \mathrm{S}\right.$ through $\left.42^{\circ} \mathrm{S}\right)$, has been found in 2 major spawning areas along the Chilean coast (Serra 1983, Loeb \& Rojas 1988): a northern area (southern Peru through $\left.25^{\circ} \mathrm{S}\right)$ and the Talcahuano area $\left(35^{\circ} \mathrm{S}\right.$ through $38^{\circ} \mathrm{S}$ ). Although spawning may occur intermittently during most of the year, peak reproduction in both areas is during the austral winter (July through September, Mujica \& Rojas 1980). Within each area, anchovy spawning has usually been reported close to the coast. In the Talcahuano area, near the southern limit of the anchovy distribution, 2 seasons of different oceanographic conditions occur during the year. A first period (upwelling season), from spring through the end of summer, is characterized by strong south, southwesterly winds that induce offshore movement of SubAntarctic Surface Water (SASW), and upwelling of Equatorial SubSurface Waters (ESSW) at the coast. A second period (downwelling season), from the fall to the end of winter, is characterized by the return of the SASW towards the coast and the deepening of the ESSW towards the slope. (Bernal et al. 1983, Arcos \& Navarro 1986).

Because of the differences in oceanographic regimes throughout the year, the early life stages of the Chilean anchovy spawned in different seasons should experience contrasting environmental conditions. During the winter spawning season of Engraulis ringens along the Central Chilean coast, we should expect wind field and oceanographic conditions conducive to egg and larval retention close to the coast, and low abundance of jellyfish predators. The low concentrations of larval food due to the winter conditions and the sporadic outbursts of jellyfish predators may represent two of the major tradeoffs within this reproductive strategy. In the present paper, we test these hypotheses utilizing oceanographic data and the ichthyoplankton samples collected during 8 cruises off Talcahuano during the anchovy winter spawning season of 1995 . We explore the relationships between the general oceanographic conditions (in terms of wind stress, sea surface temperature and hydrographic characteristics), the microplankton abundance and composition (as a potential food source for the larvae), and the abundance of invertebrate predators (jellyfish). This information allows us to incorporate new insight into the current hypotheses on reproductive strategies for coastal fish populations of upwelling areas. 


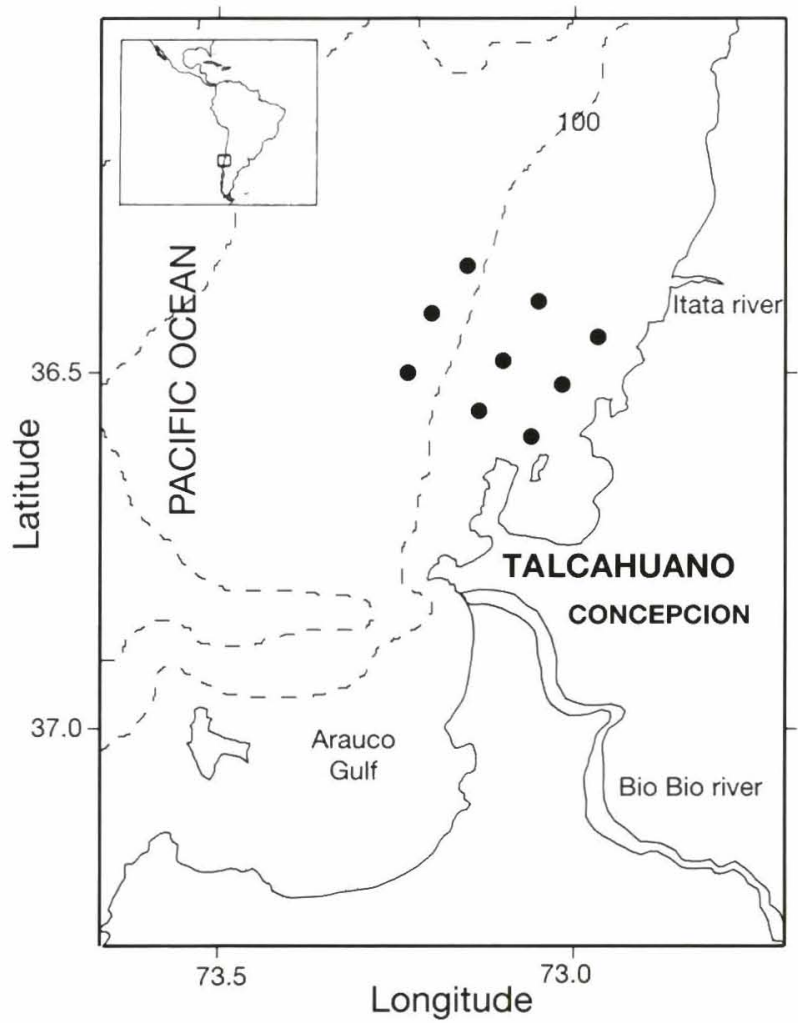

Fig. 1. Station grid sampled during the winter season of 1995 off Talcahuano, Central Chile

\section{METHODS}

A series of 8 cruises was conducted in the coastal zone off Talcahuano during the 1995 winter spawning season of Engraulis ringens (July 12, 18; August 1, 8, 17 . 30; September 4 and 11). The area surveyed consisted of a 9 station grid (Fig. 1). The central transect of 3 stations perpendicular to the coast (located 2, 7 and 12 nautical miles offshore respectively) was sampled during the 8 cruises. On 2 of these cruises (at the beginning and end of the sampling season), an extra transect was also sampled (the southern transect at the beginning of the season, and the northern at the end of the season).

At each station, ichthyoplankton samples were collected with a Bongo net ( $60 \mathrm{~cm}$ diameter, $500 \mu \mathrm{m}$ mesh), equipped with a flowmeter to quantify the volume of water filtered, from surface to $40 \mathrm{~m}$ deep (mean depth of the thermocline). One of the paired samples was preserved in $4 \%$ formalin for egg and larval identification and larval sizing, and the other sample was preserved in ethanol $(96 \%)$ for otolith work (not included here). Hydrographic characteristics of the water column (temperature, salinity and dissolved oxygen concentrations) were measured from water samples collected with $4 \mathrm{l}$ Niskin bottles at different depths (surface, 5, 10, 15, 20, $30,40,60$ and $80 \mathrm{~m}$ ). From the same depths (except 5 and $15 \mathrm{~m}$ ), water samples were collected at all stations, for later microplankton identification and counting in the laboratory. The microplankton was collected by sieving the $1 \mathrm{l}$ of seawater sample through a $41 \mu \mathrm{m}$ mesh and preserving it in $4 \%$ formalin.

In the laboratory, anchovy eggs and larvae from the formalin/ichthyoplankton samples were identified, sorted and counted. Anchovy larvae were also classified as pre- or postflexion (flexion and postflexion pooled) based on the bending of the notochord. The microplankton samples were resuspended in a standard volume, and a $60 \mathrm{ml}$ subsample per depth was analyzed for major microplankton groups. Anchovy eggs and larval concentrations are expressed throughout as number of individuals per $1000 \mathrm{~m}^{3}$, and microplankton groups are expressed as numbers per $1 \mathrm{l}$. Statistical significance was fixed at 0.05 , and all tests and graphics were performed with the SYSTAT, Inc., software package, Surfer and Sigma Plot. Hourly wind data (speed and direction) were obtained from the PETROX Meteorological Station at Talcahuano and are presented here as daily mean speed in the $v$ (northsouth) and $y$ (east-west) axis. Satellite Sea Surface Temperature (SST) images for 4 dates around the cruises in August were obtained from the NOAA-14 satellite, and the data and images were processed at the Multidisciplinary Remote Sensing Program Lab, at the Universidad de Concepcion.

\section{RESULTS}

\section{Egg and larval anchovy distribution}

Anchovy eggs dominated the fish eggs collected throughout the sampling season. Anchovy eggs were more abundant at the beginning and at the middle of the season, accounting for over 57 and $54 \%$ of all fish eggs combined in mid-July and early August 1995 respectively (Fig. 2). A total of 18 fish species (and 11

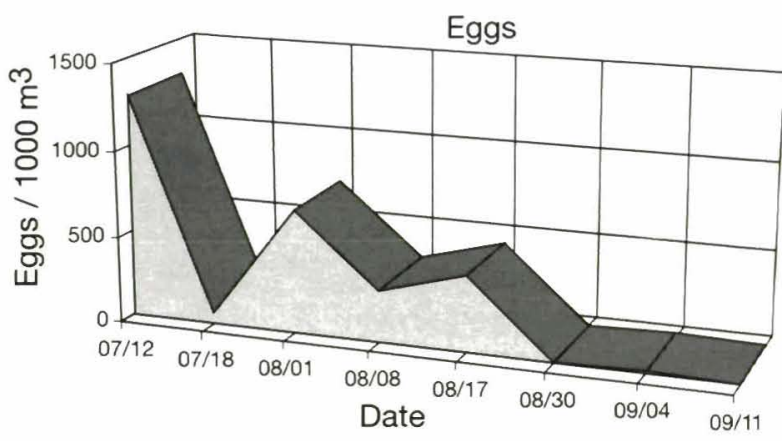

Fig. 2. Engraulis ringens. Mean density of anchovy eggs on each cruise date during the winter sampling season of 1995, off Talcahuano. Dates given as mo/d 
Table 1. Ten most abundant fish taxa collected during the 1995 winter spawning season of the anchovy Engraulis ringens off Talcahuano. Abundance is the total number of larvae collected; frequency is the number of stations of the 9 station grid at which the larvae were collected; mean density is the average larval density at the positive stations; maximum density is the maximum larval density collected at a single station

\begin{tabular}{|c|c|c|c|c|c|}
\hline Taxon & $\begin{array}{l}\text { Abundance } \\
\text { (ind.) }\end{array}$ & $\begin{array}{l}\text { Proportion } \\
(\%)\end{array}$ & $\begin{array}{c}\text { Frequency } \\
\text { (no. of stations) }\end{array}$ & $\begin{array}{c}\text { Mean density } \\
\text { (ind. per } 1000 \mathrm{~m}^{3} \text { ) }\end{array}$ & $\begin{array}{c}\text { Max. density } \\
\text { (ind. per } 1000 \mathrm{~m}^{3} \text { ) }\end{array}$ \\
\hline Hygophum sp. & 967 & 42.8 & 9 & 367 & 932 \\
\hline Engraulis ringens & 580 & 25.7 & 7 & 232 & 247 \\
\hline Strangomera bentincki & 188 & 8.3 & 6 & 120 & 251 \\
\hline Sebastes capensis & 108 & 4.8 & 7 & 47 & 44 \\
\hline Paralichthys adpersus & 82 & 3.6 & 9 & 33 & 32 \\
\hline Normanichthys crockeri & 69 & 3.1 & 6 & 39 & 50 \\
\hline Hypsoblennius sordidus & 68 & 3.0 & 8 & 25 & 30 \\
\hline Merluccius gayi & 45 & 2.0 & 8 & 28 & 71 \\
\hline Odontesthes regia & 23 & 1.0 & 1 & 123 & 120 \\
\hline Etmidium maculatum & 20 & 0.9 & 2 & 33 & 23 \\
\hline E. ringens eggs & 2836 & 20.9 & 16 & 881 & 4392 \\
\hline Other fish eggs & 10683 & 79.1 & 29 & 1330 & 14019 \\
\hline
\end{tabular}

unidentified types) was identified in the larval collections. The myctophid Hygophum sp., the anchovy Engraulis ringens and the common sardine Strangomera bentincki dominated the larval fish collection during the winter of 1995 , representing together over $75 \%$ of all larvae combined (Table 1). Hygophum sp. and Paralichthys adpersus were the most frequent fish taxa in the area (collected at all 9 stations), followed by the blenniid Hypsoblennius sordidus and the hake Merluccius gayi, which were collected at 8 out of the 9 stations in the grid.

The abundance of anchovies changed throughout the sampling season. Unlike the anchovy eggs, larval anchovies were more abundant only at the middle of the sampling season (i.e. August 8 to 30; Fig. 3), accounting for over $41 \%$ of all larvae combined (all taxa pooled). Maximum preflexion larval densities and

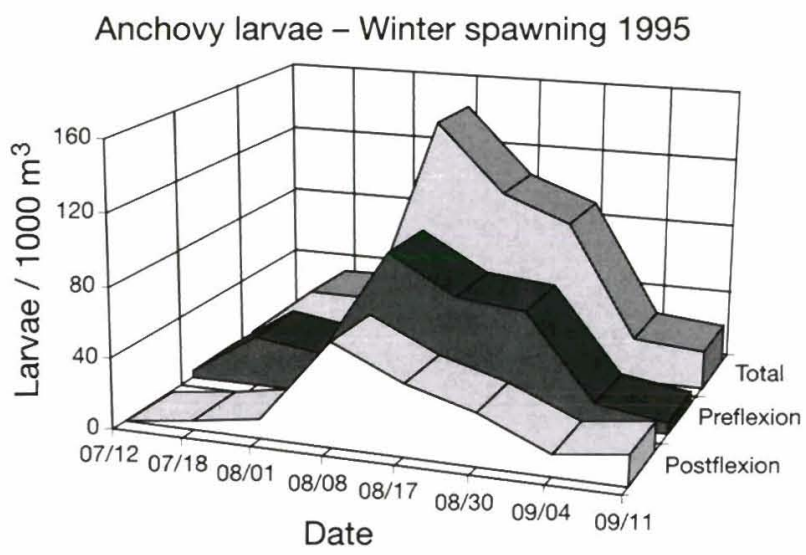

Fig. 3. Engraulis ringens. Mean density of preflexion, postflexion and total anchovy larvae on each cruise date during the winter sampling season of 1995, off Talcahuano maximum postflexion larval densities occurred simultaneously in the middle of the sampling season (August 8 through 30). Abundance decreased from the egg stage, to the preflexion stage and finally to the postflexion larval stage (Figs. $2 \& 3$ ).

The anchovy eggs and larvae tended to occur in higher densities closer to the coast, although differences in distributions were observed among dates (Fig. 4).
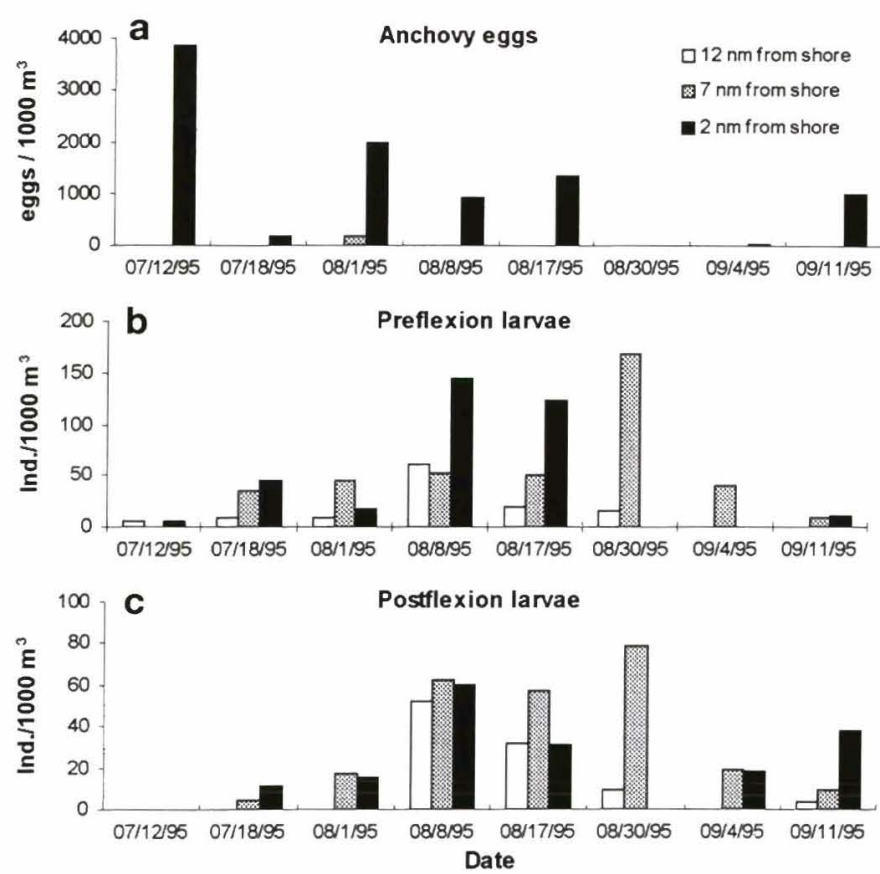

Fig. 4. Engraulis ringens. Distribution of anchovy (a) eggs, (b) preflexion larvae and (c) postflexion larvae during the winter sampling season of 1995, at 3 stations $(2,7$ and 12 nautical miles offshore) off Talcahuano. Sampling dates are shown for reference (nm, nautical miles) 
Anchovy eggs were always more abundant nearshore; the preflexion larval stages, in lower densities than the eggs, were also more abundant nearshore, except on August 8 under the river plume influence and upwelling conditions (see below), when they occurred in higher densities at a mid-distance between shore and offshore. Finally, the postflexion anchovy larvae were also abundant close to the coast but occurred at a middistance between shore and offshore on the same date that preflexion larvae were located offshore (August 8).

\section{Gelatinous predators and chaetognaths}

Four groups of potential fish egg and larval predators (Hunter 1984, Bailey \& Houde 1989) were quantified: medusae and ctenophores (here treated together), siphonophores and chaetognaths. Medusae and ctenophores were more abundant at the beginning and at the end of the sampling season (i.e. late July and early September; Fig. 5a), in contrast to larval anchovy densities. Siphonophores were also abundant at the end of the sampling period (Fig. 5b). Chaetognaths, on the

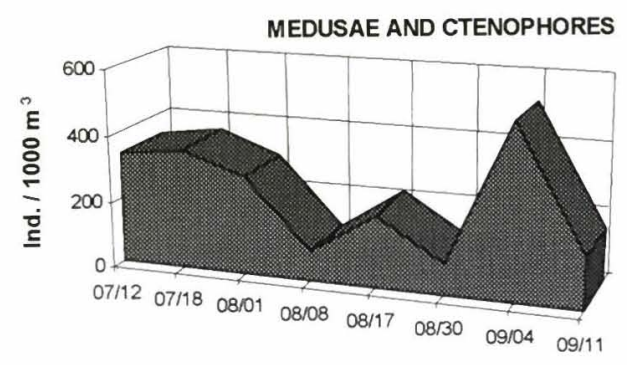

b

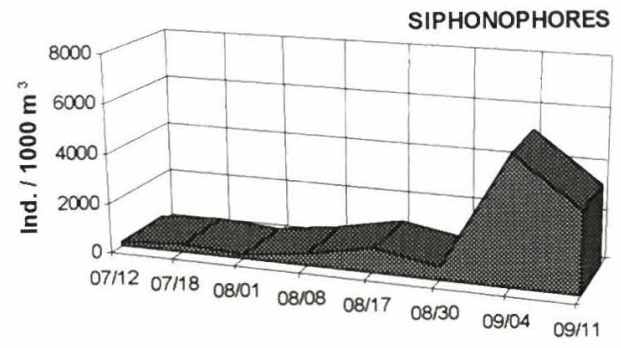

C

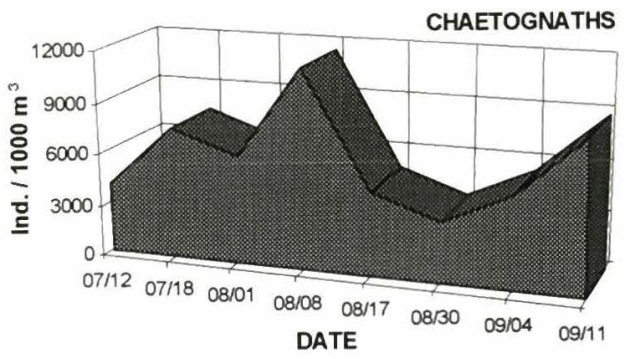

Fig. 5. Mean density of (a) medusae and ctenophores, (b) siphonophores and (c) chaetognaths on each cruise date during the winter sampling season of 1995, off Talcahuano other hand, were abundant throughout the season, with peak densities on August 8 (Fig. 5c).

In contrast to the anchovy egg and larval distributions, ctenophores and medusae were consistently more abundant offshore than onshore (Fig. 6a). Siphonophores occurred in similar numbers inshore and offshore throughout most of the season. (Fig. 6b). Chaetognath densities, finally, were variable at all stations, corresponding to the peak densities of samples collected at the inshore stations on August 8 (Fig. 6c).

\section{Microplankton composition and abundance}

Microplankton abundance was variable throughout the sampling season. Based on reports on the importance as larval anchovy food (Muck et al. 1989, Llanos 1990), the entire collection of microplankton was classified in 5 major groups: diatoms, dinoflagellates, coccolithophorids, copepods and ciliates (Table 2). Diatom, dinoflagellate and coccolithophorid densities were low during winter, reaching values at least 2 orders of magnitude lower than those reported during the spring
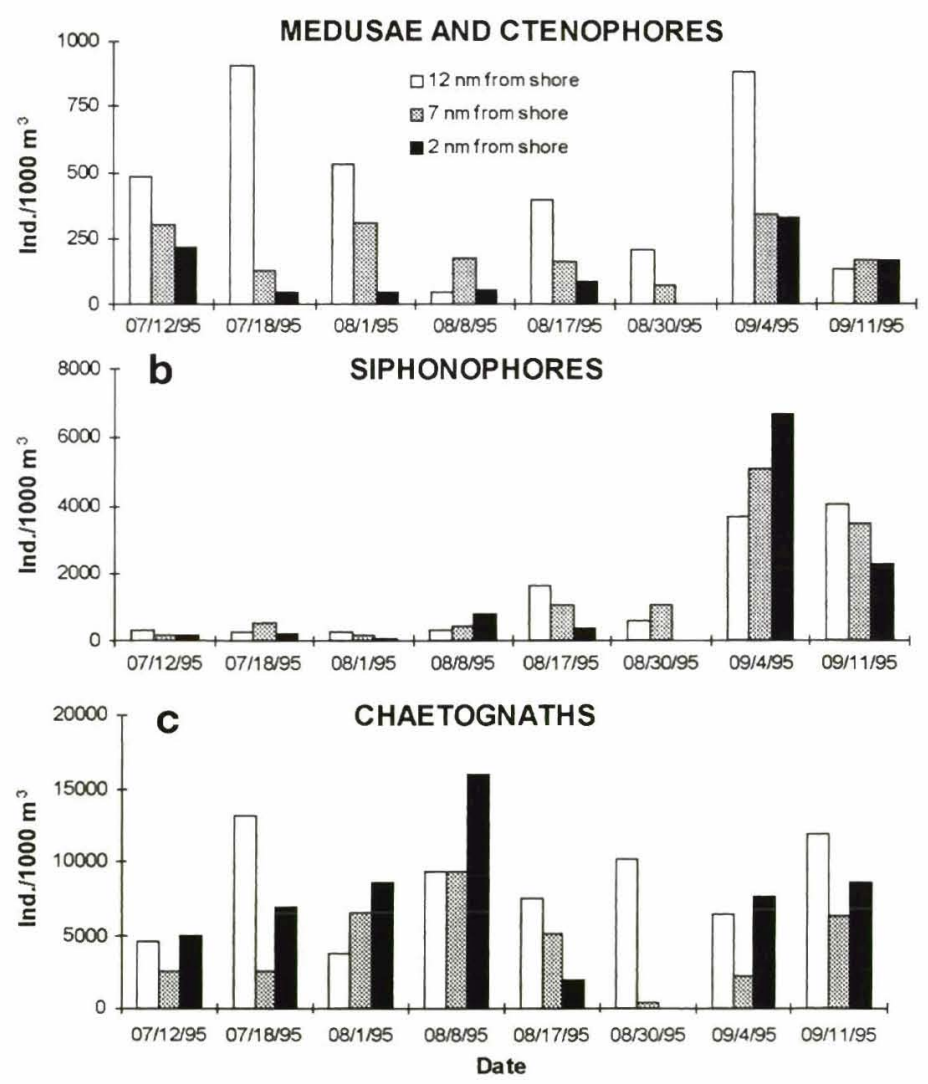

Fig. 6. Density of fish egg and larval predators at the inshore and offshore stations off Talcahuano, on each cruise date during the winter sampling season of 1995; (a) medusae and ctenophores, (b) siphonophores and, (c) chaetognaths 
and summer upwelling season (Gonzalez et al. 1987). Of the 14 diatom taxa identified, Coscinodiscus sp., a large unicellular diatom, was the most frequent and abundant, followed by Navicula, a pennate diatom, and by Chaetoceros and Skeletonema, both chain-forming diatoms. At some depths, however, phytoplankton density reached values as high as those reported during summer (Table 2, last column). Dinoflagellates were also present at all stations. The dinoflagellates most commonly cited as larval food in the Talcahuano area (Protoperidinium and Ceratium, Llanos 1990) occurred in low numbers. Ciliates (tintinnids) and coccolithophorids were also present in most samples, but their densities were lower than other microplankters. Copepod egg and nauplius densities, in turn, were high during the entire season. Copepod eggs and nauplii occurred at all stations throughout the winter. Average densities of copepod eggs and nauplii together per station (mean weighted average of column integrated from 0 to $40 \mathrm{~m}$ ) were over 35 ind. $\mathrm{l}^{-1}$, and reached values in excess of 100 during some cruises. Compared with other upwelling areas along the Chile-Peru Current, these densities may be considered high for any anchovy spawning zone (2 orders of magnitude higher than in Callao, Peru; Walsh et al. 1980) and similar to low and mid-latitude food-rich, shallow embayments (Houde \& Lodval 1984, Castro \& Cowen 1991). Total potential larval food (all particles $>41 \mu$ m diameter), therefore, occurred in high abundance during the entire season, with mean densities in excess of 759 particles $\mathrm{l}^{-1}$. Interestingly, the anchovy egg densities throughout the season followed a pattern similar to that of total larval food (mean from samples from 5 depths per station) (Fig. 7; Spearman's rank correlation, Rho $=0.738, \mathrm{p}<0.05$ ).

Table 2. Microplankton taxa collected during the 1995 winter spawning season of the anchovy Engraulis ringens, off Talcahuano. Station frequency is the total number of stations at which the larvae were collected (out of the 28 stations sampled during the 8 cruises); mean weighted average is the average density of the taxa throughout the water column at each station (integral from surface to $40 \mathrm{~m}$, divided by $40 \mathrm{~m}$ ); mean density at depth is the average density of all 5 depths sampled at each station; maximum density is the maximum density of the taxa collected at any single station

\begin{tabular}{|c|c|c|c|c|c|}
\hline Taxon & $\begin{array}{l}\text { Station } \\
\text { frequency } \\
\text { (no.) }\end{array}$ & $\begin{array}{l}\text { Proportion station } \\
\text { frequency } \\
(\%)\end{array}$ & $\begin{array}{l}\text { Mean weighted } \\
\text { average } \\
\left(\text { no. } \mathrm{l}^{-1}\right)\end{array}$ & $\begin{array}{l}\text { Mean density } \\
\text { at depth } \\
\left(\text { no. } 1^{-1}\right)\end{array}$ & $\begin{array}{c}\text { Max. density } \\
\text { at depth } \\
\left(\text { no. } l^{-1}\right)\end{array}$ \\
\hline \multicolumn{6}{|l|}{ Diatoms } \\
\hline Asterionella sp. & 4 & 17.4 & 0.30 & 7 & 23 \\
\hline Biddulfia sp. & 3 & 13.0 & 0.10 & 6 & 7 \\
\hline Chaetoceros sp. & 8 & 34.8 & 0.61 & 9 & 53 \\
\hline Coscinodicus sp. & 23 & 100.0 & 373.24 & 400 & 5972 \\
\hline Hyalodiscus sp. & 1 & 4.3 & 0.06 & 11 & 12 \\
\hline Melosira sp. & 1 & 4.3 & 0.04 & 4 & 4 \\
\hline Navicula sp. & 22 & 95.7 & 1.75 & 5 & 13 \\
\hline Nitzchia sp. & 5 & 21.7 & 0.28 & 5 & 5 \\
\hline Pinnularia sp. & 2 & 8.7 & 0.06 & 4 & 4 \\
\hline Stephanopyxis sp. & 2 & 8.7 & 0.12 & 6 & 9 \\
\hline Skeletonema sp. & 7 & 30.4 & 0.79 & 9 & 57 \\
\hline Synedra sp. & 2 & 8.7 & 0.11 & 4 & 4 \\
\hline Thalassiosira sp. & 4 & 17.4 & 0.22 & 6 & 12 \\
\hline Thalasiothrix sp. & 1 & 4.3 & 0.02 & 4 & 4 \\
\hline Total & & & 377.70 & 478.77 & \\
\hline \multicolumn{6}{|l|}{ Dinoflagellates } \\
\hline Ceratium sp. & 4 & 17.4 & 0.74 & 8 & 14 \\
\hline Triceratium sp. & 1 & 4.3 & 0.01 & 3 & 3 \\
\hline Protoperidinium sp. & 4 & 13.0 & 0.28 & 7 & 10 \\
\hline Other dinoflagellates & 23 & 100.0 & 202.37 & 205 & 780 \\
\hline Total & & & 203.40 & 222.60 & \\
\hline \multicolumn{6}{|l|}{ Coccolithophorids } \\
\hline Sp. 1 & 7 & 30.4 & 0.33 & 4 & 8 \\
\hline \multicolumn{6}{|l|}{ Copepods } \\
\hline Eggs & 23 & 100.0 & 9.87 & 11 & 103 \\
\hline Naulplii & 23 & 100.0 & 25.68 & 29 & 105 \\
\hline Remains of nauplii & 1 & 4.3 & 0.33 & 9 & 19 \\
\hline Total & & & 35.88 & 48.89 & \\
\hline \multicolumn{6}{|l|}{ Ciliates } \\
\hline Tintinids & 22 & 95.7 & 2.36 & 5 & 61 \\
\hline Total & & & 619.67 & 759.45 & \\
\hline
\end{tabular}


There was good correspondence among the total abundance of dinoflagellates, copepod eggs and copepod nauplii throughout the season. After a small decrease in density from July to early August, the peak density for these 3 items during the season occurred on August 8; this was followed by another small peak in early September. Total diatoms, on the other hand, reached peak densities early in the season (mid-July) followed by intermediate densities on August 8. Densities in excess of 100 particles $l^{-1}$ were determined throughout the sampling season when all potential larval food particles $(>41 \mu \mathrm{m})$ per station on each cruise date were added together. Peak densities occurred early in the season (when the peak anchovy egg density occurred) and also during the first week of August (when a secondary peak of eggs was found and when the maximum larval densities started to develop) (Fig. 8).

\section{Winds, hydrographic conditions and SST}

The wind regime during 1995 followed the normal seasonal pattern at this latitude: winds blew from the northern quadrants during winter, and from the southern quadrants during mid-spring through mid-
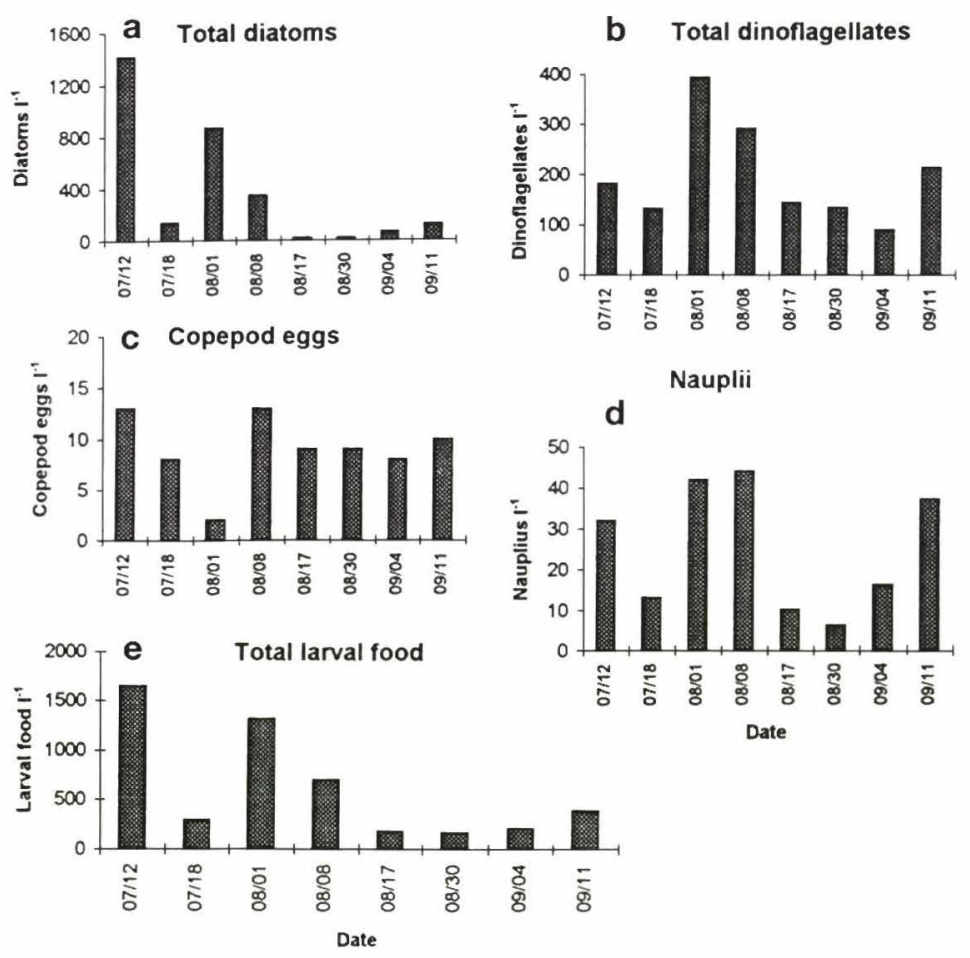

Fig. 7. Mean density of microplankton major groups in each cruise during the winter sampling season of 1995 off Talcahuano; (a) diatoms, (b) dinoflagellates, (c) copepod eggs, (d) copepod nauplii and (e) total microplankton $>41 \mu \mathrm{m}$ in diameter

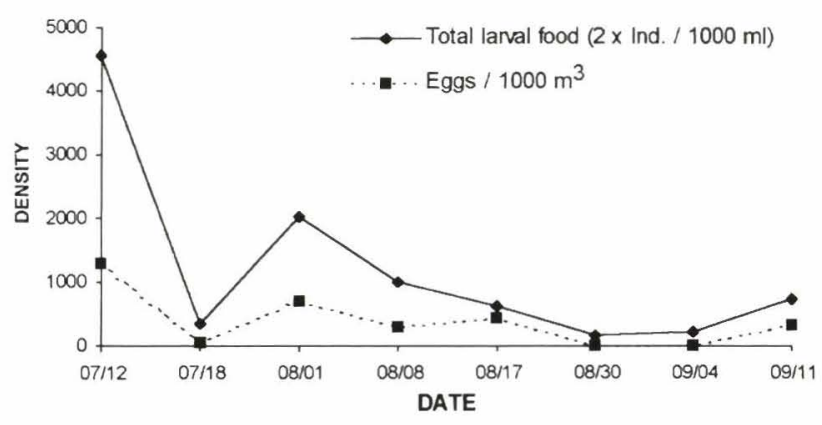

Fig. 8. Mean density of total potential larval food (microplankton $>41 \mu \mathrm{m}$ in diameter) and mean anchovy Engraulis ringens egg density on each cruise date during the winter sampling season of 1995, off Talcahuano

fall (Fig. 9). On a daily basis, however, alternating periods of northerly and southerly winds lasting for about 5 to $9 \mathrm{~d}$ each occurred during the winter sampling season of 1995 (Fig. 10). North wind periods lasting longer than $4 \mathrm{~d}$ occurred on July 21 to 27, on August 10 to 14 and from August 20 through 28. It was also during this last period that the highest north wind speeds were recorded, reaching mean daily speeds of over $4 \mathrm{~m} \mathrm{~s}^{-1}$ for a period of at least $4 \mathrm{~d}$. Southerly upwelling-favorable winds that lasted longer than $4 \mathrm{~d}$ were recorded on July 12 to 20 , from July 28 to August 9, from August 15 to 19 and finally at the end of winter from September 7 through 11.

Similar to the wind fluctuations, alternating oceanographic conditions (periods of normal winter downwelling, upwelling, and expansion of the river plume) occurred. The vertical sections of Sigma- $t$ along the central transect of the grid of stations revealed the short-term changes in the oceanographic conditions. The highly stratified water column, with the presence of a low salinity coastal plume and the subsurface approach of the dense ESSW on August 8, for instance, gave way to less stratified conditions on August 17, when the river plume signal on the surface and the denser ESSW at depth were no longer noticeable (Fig. 11). The presence of the ESSW, which usually approaches the coast in spring and summer, was revealed on August 8 by the presence below $30 \mathrm{~m}$ of low temperature water $\left(<11.1^{\circ} \mathrm{C}\right)$, low oxygen concentrations $\left(<2 \mathrm{ml} \mathrm{O}_{2} \mathrm{I}^{-1}\right)$ and high salinity (>34.533), values within the ranges reported for ESSW at this latitude (Bernal et al. 1983). On August 17 , however, when the winter conditions resumed, salinity at the same depth $(30 \mathrm{~m})$ decreased to 34.228 , temperature increased to $11.5^{\circ} \mathrm{C}$, and the dissolved oxygen values increased again to values higher than $4 \mathrm{ml} \mathrm{O}_{2} \mathrm{l}^{-1}$. 


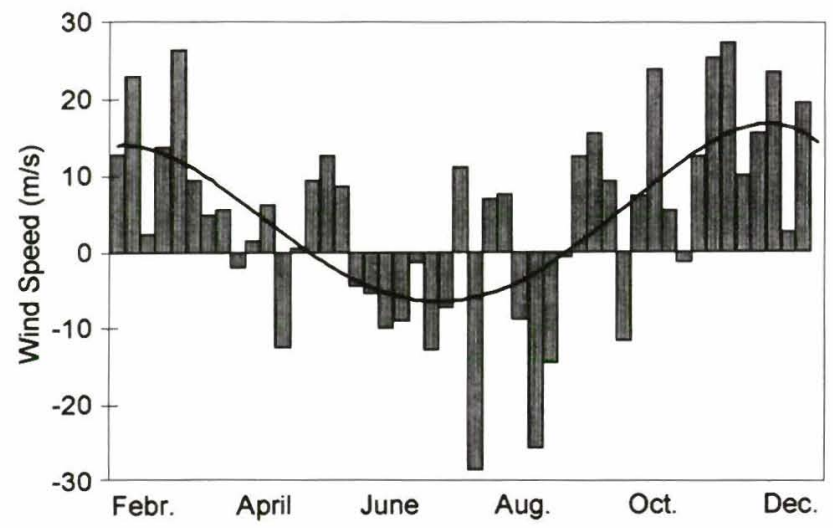

Fig. 9. Mean weekly wind intensity along a north-south axis, from February through December 1995 in the Talcahuano area. Continuous line shows the general tendency throughout the year

Satellite image sequences of SST during August 1995 show some of the high variability of the oceanographic regime during the winter of 1995 (Fig. 12). Particularly evident are the fast changes in SST from August 9 to August 15 resulting from the combined effects of the switches in oceanographic conditions from coastal upwelling and the cold river plume extending offshore (Fig. 12a) to the downwelling conditions induced by the warmer surface waters moving shoreward the following week (August 15), due to northerly winds from August 10 to 14 (Fig. 12b). Similarly, on August 28, after $9 \mathrm{~d}$ of northerly winds, another period of warming of the coastal surface water was detected by the SST satellite images. On this date, the general surface warming over the entire area co-occurred with the shoreward displacement of the thermal front (i.e. at $36^{\circ} 20^{\prime} \mathrm{S}, 73^{\circ} 30^{\prime} \mathrm{W}$ ) usually located offshore (Fig. 12c).

\section{DISCUSSION}

Anchovy species around the world utilize a wide variety of environments for spawning and as nursery areas. While some species spawn in coastal upwelling areas of moderate wind speeds (i.e. Engraulis ringens off Peru; Bakun 1996) or even inside calm shallow bays and sounds (Anchoa mitchilli along the Northeast Atlantic; Leak \& Houde 1987, Castro \& Cowen 1991), other species spawn in more advective environments that in-

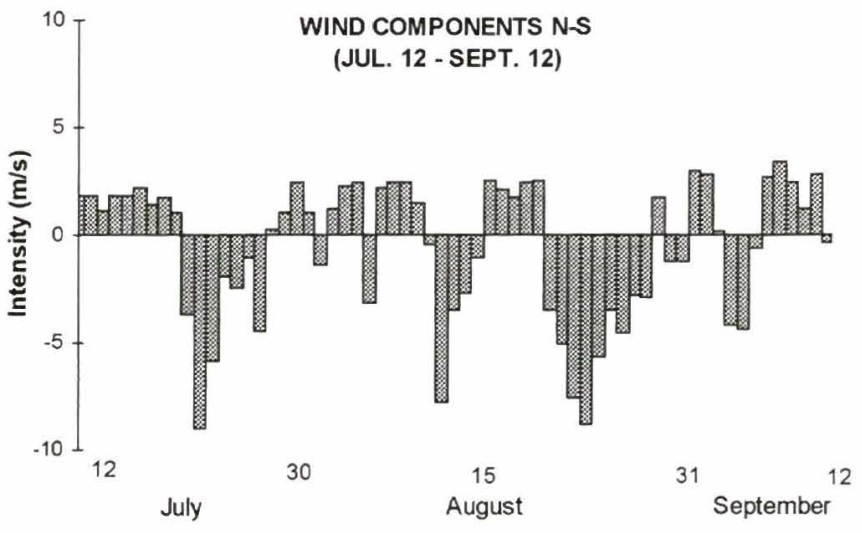

Fig. 10. Daily north-south wind intensity components during the 1995 winter sampling season of 1995 in the Talcahuano area

duce larval transport towards benign nursery areas (Engraulis capensis off southern Bengella; Huggett et al. 1998, Hutchings et al. 1998). Despite this wide variety of environments, all these species seem to share the same pattern of selecting areas where larval survival is enhanced by the presence of extremely high larval food levels or conditions of turbulence that promote larval food and larval anchovy encounter rates (Cury \& Roy 1989, Bakun 1996). In the present study we have documented the environmental conditions of the anchovy spawning area off Talcahuano during the winter of 1995; in this area the larval feeding conditions had been assumed to be harsh during winter, due to the strong wind-induced turbulent mixing (Bakun \& Parrish 1982) and the potentially decreased larval food abundance compared to the more productive summer season.

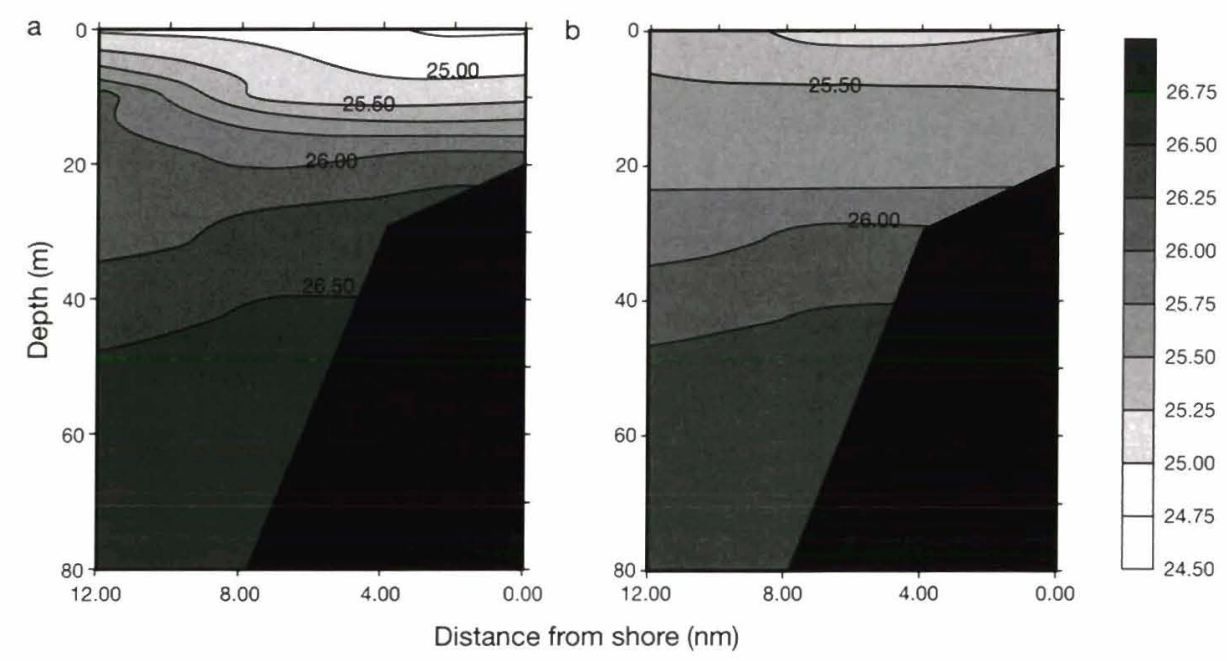

Fig. 11. Vertical sections of density (Sigma-t) along the central transect of the sampled grid during (a) upwelling (August 8) and (b) downwelling (August 15) conditions in 1995 
Larvae of the anchovy Engraulis ringens were more abundant during August, at the end of the austral winter season. This period was characterized by strong changes in wind speed and direction. Based on a detailed wind data analysis and the study of an upwelling index for Talcahuano reported by Arcos \& Navarro (1986), August is usually the first month in which the wind pattern of the area changes from the quasi-permanent northerly winds during winter, to intermittent south wind periods. Short intermittent periods of intense southerly winds occurred during our study and were responsible for inducing, for instance, the subsurface approach to the coast of waters with higher salinity and lower oxygen content (ESSW) during the beginning of the second week of August in 1995. Upwelling events, although not as frequent as during the rest of the year (i.e. spring and summer), might occur during winter in the Talcahuano area and, therefore, might bring nutrients to the surface layer inducing higher levels of productivity during the major spawning season of $E$. ringens.

The high environmental variability at the Talcahuano area does not support the hypothesis that anchovies spawn preferentially during periods of greater water column stability, in order to increase larval survival in food-rich layers (Lasker 1975, 1978). By analyzing individual events throughout the sampling season, however, periods of relative stability of the water column may have occurred, for instance, during periods of moderate southerly winds and on days of weak changes in wind direction. Similarly, the strong thermohaline differences between layers and among water masses

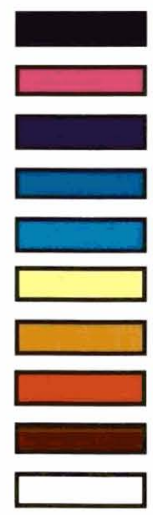

$$
\begin{aligned}
& \text { LAND } \\
& 6.0-7.0 \\
& 7.0-8.0 \\
& 8.0-9.0 \\
& 9.0-10.0 \\
& 10.0-11.0 \\
& 11.0-12.0 \\
& 12.0-13.0 \\
& 13.0-14.0 \\
& \text { CLOUDS }
\end{aligned}
$$

Fig. 12. Satellite images of sea surface temperature $\left({ }^{\circ} \mathrm{C}\right)$, showing the variability of mesoscale features and across-shelf displacement of surface waters in the Talcahuano area on (a) August 9; (b) August 15 and (c) August 28
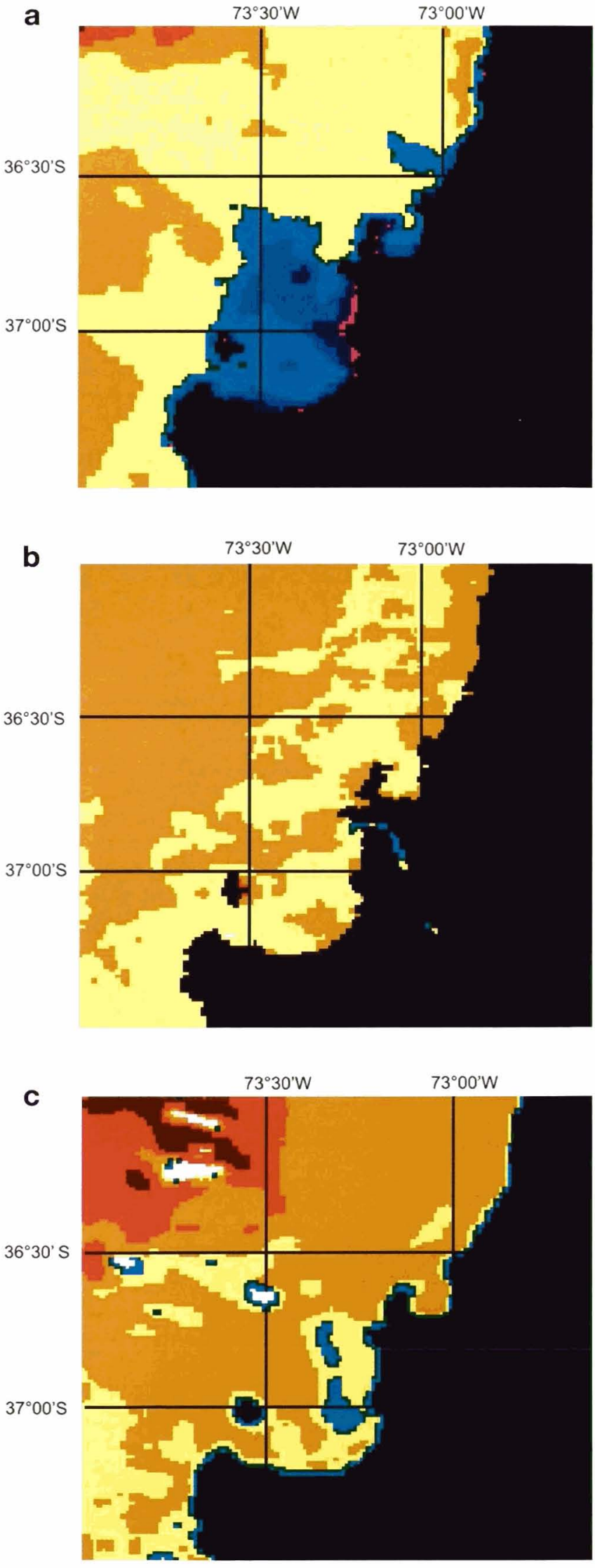


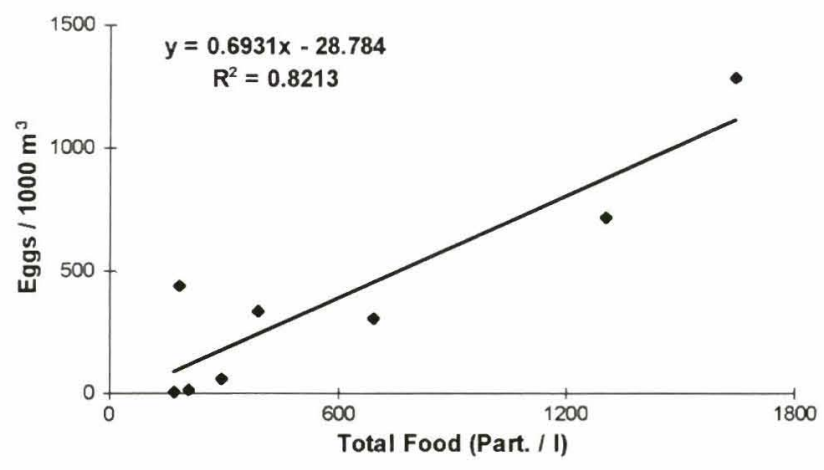

Fig. 13. Relationship of mean anchovy Engraulis ringens egg density and total larval food (microplankton $>41 \mu \mathrm{m}$ in diameter particles $\mathrm{l}^{-1}$ ) in the Talcahuano area during the winter spawning season of 1995

over the entire area may have enhanced the formation of larval food patches, both vertically and horizontally. The water masses influencing the area in winter are of various origins and characteristics: the ESSW is characterized by a low dissolved oxygen content $(0.8$ to $\left.1.3 \mathrm{ml} \mathrm{l}^{-1}\right)$, high salinity (34.5 to 34.6$)$ and low temperature $\left(8.5^{\circ} \mathrm{C}\right)$; the SASW is from a low salinity $(34.1$ to $34.2)$ and highly oxygenated ( $>4 \mathrm{ml} \mathrm{l}^{-1}$ ) coastal branch of the Chile-Peru Current, and both the waters from the Bio-Bio River plume as well as runoff enter the narrow coastal band (Bernal et al. 1983, Strub et al. 1996). Our analysis of the microplankton samples showed high larval food densities during the sampling season that, interestingly, matched the distribution and timing of the anchovy eggs and larvae $\left(R^{2}=0.8213\right.$, $\mathrm{n}=8, \mathrm{p}<0.01$; Fig. 13). In this way, although the overall stability of the water column may have been low throughout the season, patches of larval food resulted anyway from the widespread distribution of multiple frontal structures (haline and thermal) over the entire area.

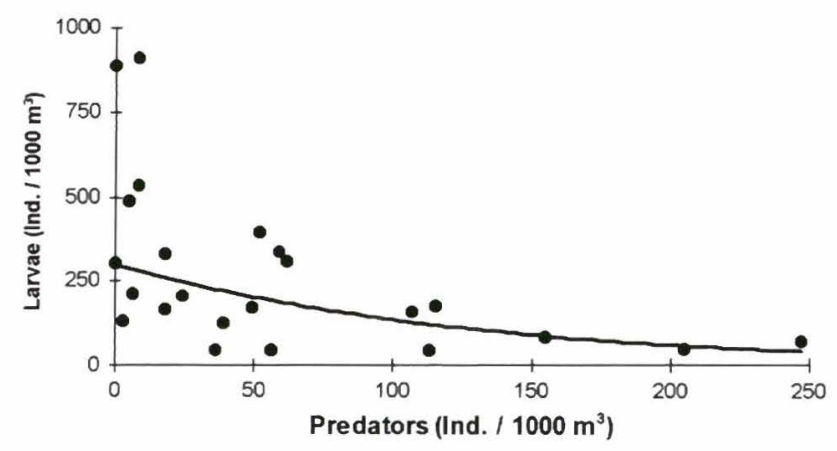

Fig. 14. Relationship of total anchovy Engraulis ringens larval density (preflexion and postflexion pooled) and gelatinous predators in the Talcahuano area during the winter sampling season of 1995
The onshore displacement of the warm surface water mass induced the increase in density of gelatinous predators nearshore. Just a few days before the nearshore peak in jellyfish density (July 12 and September 4), the local wind field showed a strong northerly component that may have driven surface waters and jellyfish onshore. On these 2 dates, minimal concentrations of anchovy larvae were collected, especially offshore, where the gelatinous predators were more abundant. In this way, the spatial distributions of fish larvae and gelatinous predators temporarily did not overlap, at least as detected by our catches, creating an apparent inverse relationship between predators and larval fish (Spearman's rank correlation, Rho $=-0.563$, $\mathrm{n}=23, \mathrm{p}<0.05$; Fig. 14). This apparent decoupling of larval fish and jellyfish abundance was also evident in times of upwelling events and of the river plume expansion (August 7 to 9). During those events, egg and anchovy larvae were transported offshore in the surface layer. This seaward displacement of cold coastal surface water induced the movement of the offshore warmer waters to an even more offshore location. Egg and larval anchovies and jellyfish predators, therefore, occurred in water masses of different characteristics, as has previously been reported for the California Current (Hunter 1984) and other temperate areas (Frank \& Legget 1985).

The coupling between peak larval fish density and the seasonal wind pattern and winter oceanographic conditions, the temporal and spatial decoupling between gelatinous predators and larval anchovies, and the overall benign larval feeding conditions close to shore suggests that the timing of spawning and nearshore location of larval anchovy may be part of an adaptive reproductive strategy. Selection of spawning areas based on arrays of environmental factors have been reported for other temperate coastal fishes for which their spawning areas have been called 'safe sites' (Frank \& Legget 1982) or 'favorable reproductive habitats' (Bakun 1996). The timing and location of Engraulis ringens spawning, therefore, seems not to be tied to a single environmental characteristic but to a set of environmental factors that may increase the chances of their egg and larval survival. Future studies on factors affecting young anchovy recruitment in Central Chile, therefore, will need to include a multiple-factor approach (larval food, transport and predators) in conjunction with mesoscale hydrodynamics to assess the potential causes for the success and/or failure of particular anchovy year classes.

Acknowledgements. Funding for this project was provided by FONDECYT Project 3950024, to L.R.C., and also partially by FONDAP, Subprogram Advanced Studies in the Hulboldt Current System. The authors of this paper thank Mrs M. Rod- 
riguez and Mrs V. Madrid for their assistance at the lab with the ichthyoplankton and microplankton samples. Mr A. Lopez at the Multidisciplinary Program on Remote Sensing Lab at the Universidad de Concepcion processed all satellite images. Mr Claudio Seguel (the late) from PETROX Meteorological Station provided the wind data, and people at the Kay Kay Research Vessel of the Universidad de Concepcion provided help at sea.

\section{LITERATURE CITED}

Arcos D, Navarro N (1986) Analysis of an upwelling index for Talcahuano, Chile (Lat. $37^{\circ} \mathrm{S}$ ). Invest Pesq (Chil) 33:91-98

Bailey KM, Houde ED (1989) Predation on egg and larvae of marine fishes and the recruitment problem. Adv Mar Biol $25: 1-83$

Bakun A (1996) Patterns in the ocean: ocean processes and marine population dynamics. University of California Sea Grant, San Diego, USA, in cooperation with Centro de Investigaciones Biologicas del Noroeste, La Paz, Baja California Sur, Mexico

Bakun A, Parrish RH (1982) Turbulence, transport, and pelagic fish in the California and Peru Current Systems. Calif Coop Ocean Fish Invest Rep 23:99-112

Barnett AM, Jahn AE, Sertic PD, Watson W (1984) Distribution of ichthyoplankton off San Onofre, California, and methods for sampling very shallow coastal waters. Fish Bull 82(1):97-111

Bernal PA, Robles FL, Rojas O (1983) Variabilidad fisica y biologica en la region meridional del sistema de corrientes Chile-Peru. FAO Fish Rep 291:683-711

Boehlert GW, Watson W, Sun LC (1992) Horizontal and vertical distributions of larval fishes around an isolated oceanic island in the Tropical Pacific. Deep-Sea Res 39(3/4): 439-466

Brewer GD, Kleppel GS (1986) Diel vertical distribution of larvae and their prey in nearshore waters of Southern California. Mar Ecol Prog Ser 27:217-226

Castro L (1995) Ichthyoplankton distribution around Barbados: patterns and processes conducive to retention. $\mathrm{PhD}$ dissertation, State University of New York at Stony Brook

Castro LR, Cowen RK (1991) Environmental factors affecting the early life history of bay anchovy, Anchoa mitchilli, in Great South Bay, New York. Mar Ecol Prog Ser 76:235-247

Castro LR, Bernal PA, Troncoso VA (1993) Coastal intrusion of copepods: mechanisms and consequences in the population biology of Rhincalanus nasutus. J Plankton Res 15(5): 501-515

Cowen RK, Castro LR (1994) Relation of coral reef fish larval distributions to island scale circulation around Barbados, West Indies. Bull Mar Sci 54(1):228-244

Cury P, Roy C (1989) Optimal environmental window and pelagic fish recruitment success in upwelling areas. Can J Fish Aquat Sci 46:670-680

Cushing D (1975) Marine ecology and fisheries. Cambridge University Press, London

Foster SA (1987) Diel and lunar patterns of reproduction in the Caribbean and Pacific seargent major damselfishes Abudefduf saxatilis and A. troschelii. Mar Biol 95:333-343

Frank KT, Legget WC (1982) Coastal water mass replacement: its effect on zooplankton dynamics and the predator-prey complex associated with larval Capelin (Mallotus villosus). Can J Fish Aquat Sci 39:991-1003

Frank K, Legget WC (1985) Reciprocal oscillations in densities of larval fish and potential predators: a reflection of present or past predation? Can J Fish Aquat Sci 42:1841-1849
Gonzalez H, Bernal P, Ahumada R (1987) Desarrollo dedominancia local en la taxocenosis de fitoplancton de Bah'ia Concepcion, Chile, durante un evento de surgencias. Rev Chil Hist Nat 60:19-35

Houde ED, Lodval JA (1984) Seasonality of occurrence, foods and food preferences of ichthyoplankton in Biscayne Bay, Florida. Estuar Coast Shelf Sci 18:403-419

Huggett JA, Boyd AJ, Hutchings L, Kemp AD (1998) Weekly variability of clupeoid eggs and larvae in the Benguela Jet Current: implications for recruitment. S Afr J Mar Sci 19: 197-210

Hunter JR (1984) Feeding ecology and predation of marine fish larvae. In: Lasker R (ed) Marine fish larvae. Morphology, ecology and relation to fisheries. University of Washington Press, Seattle

Hutchings L, Barange M, Bloomer SF, Boyd AJ, Crawford RJ, Huggett JA, Kerstan M, Korrubel JL, De Oliveira JA, Painting SJ, Richardson AJ, Shannon LJ, Sculein FH, Van Der Lingen CD, Verheye HM (1998) Multiple factors affecting South African anchovy recruitment in the spawning, transport and nursery areas. S Afr J Mar Sci 19:211-225

Jahn AE, Lavenberg RJ (1986) Fine-scale distribution of nearshore, suprabenthic fish larvae. Mar Ecol Prog Ser 31: 223-231

Johannes RE (1978) Reproductive strategy of coastal marine fishes in the tropics. Environ Biol Fishes 3:65-84

Lasker R (1975) Field criteria for survival of anchovy larvae: the relation between inshore chlorophyll maximum layers and successful first feeding. Fish Bull 73:453-462

Lasker R (1978) The relations between oceanographic conditions and larval anchovy food in the California Current: identification of factors contributing to recruitment failure. Rapp PV Reun Cons Int Explor Mer 173:212-230

Leak JC, Houde ED (1987) Cohort growth and survival of bay anchovy, Anchoa mitchilli, larvae in Biscayne Bay, Florida. Mar Ecol Prog Ser 37:109-122

Llanos A (1990) Sobreposicion dietaria de estados larvales de cuatro especies de clupeiformes en la Bahia de Concepcion. Tesis para opar al grado de Licenciado en Ciencias Biologicas, Pontificia Universidad Catolica de Chile, Sede Talcahuano

Lobel PS (1989) Ocean current variability and the spawning season of Hawaiian reef fishes. Environ Biol Fishes 24(3): 161-171

Lobel PS, Robinson AR (1986) Transport and entrapment of fish larvae by ocean mesoscale eddies and currents in Hawaiian waters. Deep-Sea Res 33(4):483-500

Lobel PS, Robinson AR (1988) Larval fishes and zooplankton in a cyclonic eddy in Hawaiian waters. J Plankton Res 10(6):1209-1223

Loeb V, Rojas O (1988) Interannual variation in chlorophyll composition and abundance off northern Chile, 1964-1982. Fish Bull 86:1-24

Muck P, Rojas De Mendiola B, Antonietti E (1989) Comparative studies on feeding in larval anchoveta (Engraulis ringens) and sardine (Sardinops sagax). In: Pauly D, Muck P, Mendo J, Tsukayama I (eds) The Peruvian upwelling ecosystem: dynamics and interactions. ICLARM Conference Proceeding 18. Instituto del Mar del Perú (IMARPE), Callao, p 86-96

Mujica A, Rojas O (1980) Estudio de reproduccion, fecundidad y desove de la sardina comun (Clupea starngomera bentincki) y de anchoveta (Engraulis ringens) de la zona de Talcahuano. In: Programa Perspectivas de desarrollo de las pesquerias nacionales. Subprograma Dinamica Poblacional de Sardina y Anchoveta, Zona de Talcahuano. Informe Tecnico IFOP AP - 80-3, Corpora- 
tion de Fomento de la Produccion (CORFO), Santiago Palma S (1994) Distribución del macrozooplancton gelatinoso en un area de desove de peces frente a la costa central de Chile $\left(32^{\circ}-33^{\circ} \mathrm{S}\right)$. Rev Biol Mar 29(1):23-45

Palma S, Rosales S (1995) Composition, distribution and seasonal abundance of macroplankton in Valparaiso Bay. Investig Mar Univ Catol Val 23:49-66

Parrish RH, Nelson CS, Bakun A (1981) Transport mechanisms and reproductive success of fishes in the California Current. Biol Oceanogr 1(2):175-203

Peterson WT, Miller CB, Hutchinson A (1979) Zonation and maintenance of copepod populations in the Oregon upwelling zone. Deep-Sea Res 26A:467-493

Roy C, Cury P, Kifani S (1992) Pelagic fish recruitment success and reproductive strategy in upwelling areas: environmental compromises. In: Payne AIL, Brink KH, Mann $\mathrm{KH}$, Hilborn R (eds) Benguela trophic functioning. S Afr J Mar Sci 12:135-146

Serra JR (1983) Changes in the abundance of pelagic re-

Editorial responsibility: Kenneth Sherman (Contributing Editor), Narrangansett, Rhode Island, USA sources along the chilean coast. FAO Fish Rep 291: $255-281$

Sherman K, Smith W, Morse W, Bernman M, Green J, Ejsymont L (1989) Spawning strategies of fishes in relation to circulation, phytoplankton production, and pulses in zooplankton off the northeastern United States. Mar Ecol Prog Ser 18:1-19

Sinclair M, Tremblay M (1984) Timing of spawning of Atlantic herring (Clupea harengus harengus) populations and the match-mismatch theory. Can J Fish Aquat Sci 41: $1055-1065$

Strub PT, Mesias J, Montecino V, Ruttland J, Salinas S (1996) Coastal ocean circulation off western South America. In: Robinson AR, Brink KH (eds) The sea, Vol 11. John Wiley \& Sons, Inc, New York, p 273-313

Walsh JJ, Whitledge TE, Esaias WE, Smith RL, Huntsman SA, Santander H, De Mendiola BR (1980) The spawning habitat of the Peruvian anchovy, Engraulis ringens. Deep-Sea Res 27A:1-27

Submitted: February 3, 1997; Accepted: October 12, 1999 Proofs received from author(s): April 28, 2000 